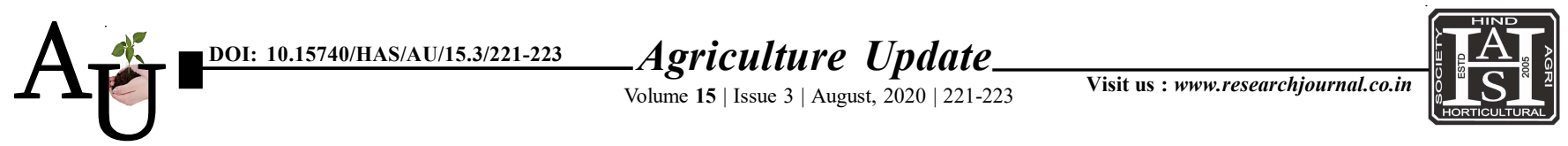

ISSN-0973-1520

\title{
Research article: Suggestions of the farm women to increase the utility of mass media
}

A. S. Lad, P. R. Deshmukh and R. P. Kadam

Article Chronicle:

Received :

24.04.2020;

Revised:

16.06.2020;

Accepted :

17.07.2020

KEY WoRDS:

Suggestions, Farm women, Utility, Mass media

Author for correspondence :

R.P. Kadam

Department of Extension Education, College of

Agriculture, Vasantrao

Naik Marathwada Krishi

Vidhyapeeth, Parbhani

(M.S.) India

Email:rpk.mkv@gmail.

com

See end of the article for

authors' affiliations
SUMMARY : The present investigation was conducted in Parbhani, Hingoli and Nanded districts in Marathwada region of Maharashtra State. A structured interview schedule was used to collect data from 150 respondents who were viewing agricultural programmes on TV, as well as listening agricultural programmes on radio and also reading agricultural articles in the newspaper. The qualitative data were quantified using suitable statistical tools. The suggestions given by the farm women to increase the utility of mass media was studied by frequency and percentage method. Regarding suggestions to improve farm telecast majority of the respondents suggested to change the telecasting time $(56.66 \%)$ and to use local language (52.66\%). Regarding suggestions to improve farm broadcast, respondents suggested to use simple language (59.33\%) and provide useful information timely (50.67\%). Regarding suggestions to improve utility of newspaper, respondents suggested that information should be given in easy language $(60.00 \%)$, case studies of experienced farm women should be published in the newspaper (54.66\%), information should be practicable (52.66\%), letters must be bold enough $(51.33 \%)$ and statistics of the nation, state and region should be avoided (46.00\%).

How to cite this article : Lad, A.S., Deshmukh, P.R. and Kadam, R.P. (2020). Suggestions of the farm women to increase the utility of mass media. Agric. Update, 15(3): 221-223; DOI : 10.15740/HAS/AU/15.3/221-223. Copyright@2020: Hind Agri-Horticultural Society. 